- FINANSE I PRAWO FINANSOWE.

- Journal of Finance and Financial Law •

Wrzesień/September 2017 • vol. 3(15): 53-64

http://dx.doi.org/10.18778/2391-6478.3.15.05

\title{
GDY ZABRAKNIE SZWAJCARSKIEJ PRECYZJI \\ - O PROBLEMIE KREDYTOBIORCÓW ZACIĄGAJĄCYCH KREDYTY WE FRANKACH SZWAJCARSKICH W ASPEKCIE PRAWNO-EKONOMICZNYM
}

Piotr Liwoch

Wydział Prawa i Administracji

Uniwersytet Jagielloński

Wydział Finansów i Prawa

Uniwersytet Ekonomiczny w Krakowie

\begin{abstract}
Streszczenie
Artykuł traktuje o problemie polskich kredytobiorców zaciągających kredyty walutowe w frankach szwajcarskich, których zobowiązanie wobec kredytodawców znacznie wzrosło na skutek silnej deprecjacji franka względem złotego polskiego. Autor w swojej pracy analizuje sytuację panującą na polskim rynku finansowym, rozważa problem odpowiedzialności banków za wzrost zadłużenia tzw. "frankowiczów”, przedstawia wybrane orzecznictwo sądów polskich oraz ocenia działania legislacyjne, które mają pomóc kredytobiorcom kredytów walutowych dotkniętych problemem znacznego wzrostu kursu waluty obcej.
\end{abstract}

Słowa kluczowe: kredyty walutowe, odpowiedzialność banków, niewłaściwe praktyki rynkowe, frank szwajcarski, działania legislacyjne.

JEL Class: G21, G28, K12, K29, K42. 


\section{WPROWADZENIE}

Historia kredytów walutowych we frankach szwajcarskich rozpoczęła się w austriackich, przygranicznych regionach, gdzie kredytobiorcami stawali się głównie pracujący i zarabiający u zachodnich sąsiadów Austriacy [www2]. $\mathrm{Z}$ biegiem czasu, zwłaszcza od momentu przystąpienia do Unii Europejskiej 10 nowych państw członkowskich w 2004 roku, w skutek rozwoju rynku globalnego i zwiększającej się konkurencyjności, zaczęła rosnąć popularność tej formy pozyskiwania kapitału wśród gospodarstw domowych wschodnioeuropejskich krajów, takich jak choćby Ukraina, Rumunia czy Węgry. Także w Polsce, dzięki silnej aprecjacji złotego względem franka (zwłaszcza w 2007 i 2008 roku), możliwość wzięcia kredytu we frankach była postrzegana za opcję bardzo atrakcyjną przede wszystkim ze względu na niskie stopy procentowe i wysokie oczekiwania względem przyszłej stabilności waluty helweckiej. Zaciągnięcie takiego rodzaju kredytu dawało możliwość zmniejszenia kosztów obsługi zadłużenia, a co za tym idzie - zmniejszenia zobowiązania pieniężnego wobec banku w stosunku do kredytu zaciągniętego w złotym. Dodatkowo, uzyskanie kredytu we franku szwajcarskim w tamtym okresie było możliwe dla osób, które nie miały zdolności kredytowej na potrzeby uzyskania kredytu w złotym.

Upadek amerykańskiego banku Lehman Brothers [Miklaszewska (red.), 2010: 35-36] w 2008 r. który zapoczątkował ogólnoświatowy kryzys gospodarczy, a także decyzja Narodowego Banku Szwajcarii ze stycznia 2015 roku w zakresie ustalenia ujemnych stóp referencyjnych LIBOR CHF 3M i ,uwolnienia" do tamtej pory stabilizowanego kursu franka do euro spowodowały wystrzelenie kursów w górę [Jurkowska-Zeidler 2016: 132], skutkującą zwiększeniem comiesięcznej raty denominowanych albo indeksowanych kredytów i wzrostem ogólnego zadłużenia konsumentów względem banku - nieraz przekraczającego w sposób znaczny wartość nieruchomości zakupionej z tego kredytu ${ }^{1}$.

Sytuacja ta stała się źródłem szerokiej debaty publicznej oraz dyskursu politycznego dotyczącego zakresu odpowiedzialności banków za wysokość zadłużenia Polaków, stosunku ponoszenia ryzyka walutowego przez obydwie strony umowy kredytowej, poziomu ochrony konsumenta na rynku finansowym oraz stanu prawnego w Polsce. Szeroko dyskutowana pozycja tzw. „frankowiczów” spowodowała wysuwanie wielu propozycji legislacyjnych pochodzących ze środowisk prawniczych, ekonomicznych i politycznych. Rozwiązanie tego problemu ma istotne znaczenie dla systemu finansowego państwa, ponieważ we-

${ }^{1}$ Mierzony za pomocą wskaźnika LTV. Wskaźnik LTV, wyrażony w procentach, informuje o stosunku wysokości kredytu do wartości zabezpieczenia (najczęściej hipotecznego). Przykładowo, jeśli wskaźnik wynosi 120\% przy wartości nieruchomości 500.000 PLN, wysokość kredytu wynosi 600.000 PLN. 
dług danych podanych przez Komisję Nadzoru Bankowego, przedstawionych w tabeli 1, stosunkowy udział kredytów mieszkaniowych walutowych w kredytach mieszkaniowych ogółem jest wysoki. Należy jednak zwrócić uwagę na fakt zwiększającego się udziału kredytów mieszkaniowych w złotówkach przy tendencji względnie stałej wysokości dla kredytów mieszkaniowych zaciąganych w walutach obcych. Świadczy to o coraz chętniejszym wyborze kredytowania gospodarstwa domowego przez polskiego konsumenta złotym polskim. Z drugiej strony pod uwagę trzeba wziąć fakt, że kredyty walutowe nadal stanowią istotną część kredytowania polskich gospodarstw domowych i mają przez to duże znaczenie systemowe.

Tabela 1. Struktura kredytów mieszkaniowych polskich gospodarstw domowych w latach 2013-2015 z podziałem na kredyty złotówkowe i kredyty walutowe

\begin{tabular}{|c|c|c|c|c|}
\hline $\begin{array}{c}\text { Kredyty mieszkaniowe } \\
\text { (w mld zł) }\end{array}$ & 2013 & 2014 & 2015 & $\begin{array}{c}2016 \\
\text { (do 09/16) }\end{array}$ \\
\hline Ogółem, w tym: & 335,7 & 355,9 & 381,3 & 392,3 \\
\hline -w złotym & 167,0 & 190,4 & 212,0 & 229,0 \\
\hline - walutowe & 168,7 & 165,5 & 169,3 & 163,3 \\
\hline
\end{tabular}

Źródło: www5.

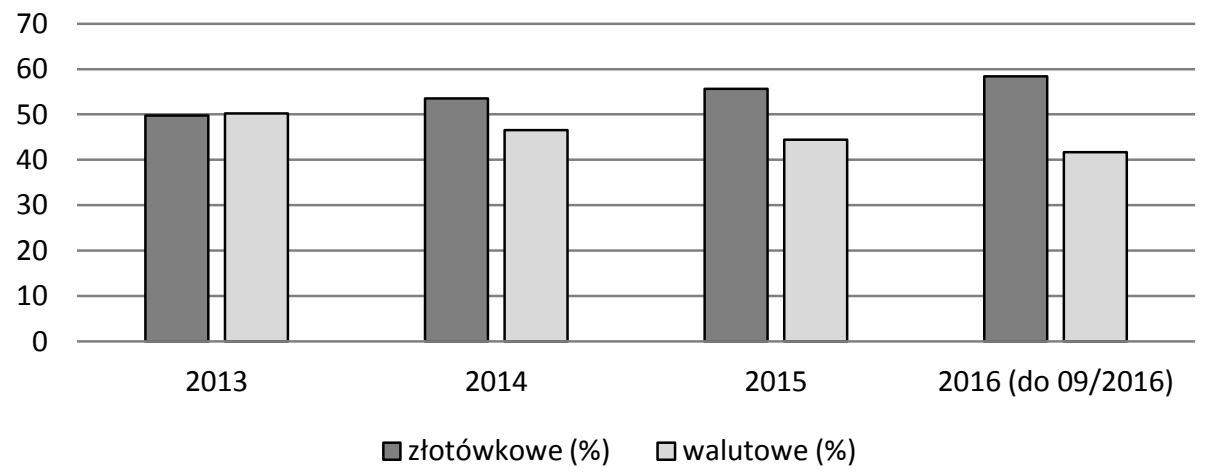

Wykres 1. Struktura procentowa kredytów złotówkowych i walutowych w latach 2013-2016

Źródło: opracowanie własne na podstawie danych z tab. 1.

Celem przedstawionej pracy jest ocena odpowiedzialności banków komercyjnych za obecną sytuację finansową kredytobiorców zaciągających kredyty walutowe we frankach szwajcarskich oraz ocena konieczności ingerencji legislacyjnej państwa w sferę stosunków cywilnoprawnych między kredytodawcami, a kredytobiorcami. W artykule - na podstawie analizy wybranych opraco- 
wań naukowych, projektów legislacyjnych oraz aktualnego stanu normatywnego - przyjęto hipotezę badawczą, że kredytodawcy ponoszą odpowiedzialność za obecny stan zadłużenia kredytobiorców zaciągających kredyty hipoteczne we frankach szwajcarskich, a także hipotezę o niecelowości wskazanych działań legislacyjnych $-\mathrm{z}$ wskazaniem obszarów, w kierunku których de lege ferenda ustawodawca powinien zmierzać.

\section{KREDYT WALUTOWY DENOMINOWANY I INDEKSOWANY - ROZRÓŻNIENIE POJĘĆ}

Na samym początku należy rozróżnić pojęcie kredytu walutowego denominowanego i kredytu walutowego indeksowanego, ponieważ często uznaje się je, błędnie, za pojęcia tożsame. Kredyt walutowy denominowany jest kredytem wyrażonym $\mathrm{w}$ walucie obcej, przy czym wypłata świadczenia ze strony kredytodawcy jest dokonywana w walucie polskiej, stanowiącej równowartość wnioskowanego świadczenia w walucie obcej według kursu na dzień wypłaty świadczenia. Wartość świadczenia zaległego kredytobiorcy podawana jest także w walucie obcej. Z kolei kredyt indeksowany jest specyficznym rodzajem kredytu wyrażanym w złotym polskim, o silnej zależności od kursu obcej waluty. Świadczenie wypłacane jest w złotym, jednak w dniu wypłaty kwoty kredytu przeliczane jest na równowartość świadczenia w walucie obcej i jest spłacane do końca okresu kredytowania w wysokości odpowiadającej bieżącemu kursowi waluty obcej. Wysokość kredytu indeksowanego wyrażona jest zatem w złotym, ale waloryzowana w stosunku do waluty obcej.

\section{ARGUMENTY PRZECIW POMOCY „FRANKOWICZOM” ORAZ ORZECZENIE TRYBUNAŁU SPRAWIEDLIWOŚCI UNII EUROPEJSKIEJ W SPRAWIE C 312/14 Z POWÓDZTWA BANIF PLUS BANK PRZECIWKO WĘGIERSKIEMU MALŻEŃSTWU LANTOS}

Udzielanie kredytów walutowych we frankach szwajcarskich przez banki doprowadziło sektor bankowy do wysokiej ekspozycji na ryzyko zmian kursowych. Deprecjacja waluty krajowej do obcej spowodowała zachwianie równowagi systemowej i doprowadziła do podjęcia aktywności legislacyjnej mającej na celu pomoc jednostkom najbardziej poszkodowanym na zasadzie społecznej solidarności. Pojawiają się propozycje polegające na pomocy w przewalutowaniu kredytów (jak chociażby na Węgrzech), czy też ograniczaniu podejmowania zachowań ryzykownych w przyszłości.

$\mathrm{W}$ dyskursie społecznym pojawia się wiele argumentów przeciwnych ewentualnej pomocy państwa „frankowiczom”. Przede wszystkim takie stanowisko argumentowane jest świadomością kredytobiorców na ryzyko walutowe, chęcią zredukowania kosztów obsługi długu (a co za tym idzie - zmniejszeniem należności wynikającej z umowy kredytu), a także niesprawiedliwością takiego rozwiąza- 
nia względem osób zaciągających kredyt w złotym polskim, które nie skusiły się na korzyści finansowe wynikające $\mathrm{z}$ niskich kosztów obsługi długu. Jak szacuje Urząd Komisji Nadzoru Finansowego w raporcie z 2016 roku, przewalutowanie kredytów udzielanych we frankach mogłoby spowodować straty w sektorze bankowym na poziomie 44-67 miliardów złotych, co skutkowałoby zmniejszeniem (w najbardziej prawdopodobnym scenariuszu!) łącznego współczynnika kapitałowego (TCR) dla 6 banków (posiadających aktywa w wysokości 344,7 mld zł, depozytów sektora niefinansowego w wysokości 208,5 mld zł oraz środków gwarantowanych w wysokości 137,8 mld zł) poniżej minimalnych 8 procent, co skutkowałoby niewypłacalnością tych banków, utratą zaufania do sektora bankowego, a w skrajnych przypadkach - do kryzysu finansowego [www4: 12].

Problem jednak zdaje się wynikać z małej świadomości kredytobiorców co do ryzyka wynikającego ze zmienności kursów walutowych, niskiej wiedzy finansowej i zbyt optymistycznych zapatrywań na stabilność kursu franka szwajcarskiego. Duże nadzieje na redukcję zadłużeń finansowych zaciągających kredytów we frankach pokładano w sprawie C-312/14 prowadzonej przed Trybunałem Sprawiedliwości Unii Europejskiej z powództwa Banif Plus Bank przeciwko węgierskiemu małżeństwu Lantos. Postawione przez węgierski sąd zapytanie o wydanie orzeczenia prejudycjalnego dotyczyło kwestii uznania klauzuli indeksacyjnej w umowie kredytu za instrument finansowy w rozumieniu dyrektywy MiFID. Liczono, że ewentualne zaaprobowanie takiego stanowiska przez TSUE będzie skutkowało nieważnością zawartych umów kredytowych. Trybunał jednak uznał, że taka klauzula nie ma na celu zabezpieczenia lub inwestycji, a tylko spłatę kredytu. Mimo to, potwierdził w wyroku, że ochrona konsumenta, wynikła zwłaszcza z dyrektywy 93/13, może prowadzić do uznania nieważności umowy przez zawieranie nieuczciwych warunków.

\section{ODPOWIEDZIALNOŚĆ BANKÓW ZA ZWIĘKSZENIE ZADŁUŻENIA KREDYTOBIORCÓW FRANKOWYCH}

Coraz częściej odpowiedzialnością za zadłużenie „frankowiczów” obarcza się banki, które nie tylko nie udzielały stosownych informacji w zakresie ryzyka wynikającego z umowy kredytu denominowanego lub indeksowanego, ale także wprowadzały do umów klauzule abuzywne w zakresie dobrowolnego regulowania spreadu przez banki i przeliczania zadłużenia według podawanego przez bank kursu sprzedaży franka, który nie był odnoszony do innych kursów (głównie zarzucało się brak odniesienia do średniego kursu NBP). Wylicza się, że różnice w spreadach, sięgające nieraz 40 groszy w porównaniu do spreadów „rynkowych”, pozwoliły bankom na osiągnięciu zysków wynikających z takich klauzul w wysokości 15,2 mld zł [www4: 33]. Abuzywność takich zapisów zostaje jednak coraz częściej stwierdzana, o czym świadczą wpisane do rejestru 
niedozwolonych klauzul umownych w 15.02.2012 r. (poz. 3178 i 3179) klauzule Banku Millenium i 08.05.2014 r. (poz. 5 743) klauzule Bre Banku.

Należy również wskazać, że klauzule wpisane do rejestru wywołują bezskuteczność tylko w stosunkach indywidualnych, a nie generalnych, ale za to działają z mocą wsteczną, dzięki czemu pozwalają na uznanie bezskuteczności regulacji dotyczących samowolnego wyznaczania spreadu przez banki od początku trwania stosunku umownego.

Próba „ukrócenia” stosowania niedozwolonych praktyk bankowych została podjęta ustawą z dnia 29.07.2011 r. o zmianie ustawy - Prawo bankowe oraz niektórych innych ustaw [Dz.U., nr 165, poz. 984], w myśl której, zgodnie $\mathrm{z}$ art. 69 ust. 2 pkt 4a, ,umowa kredytu powinna być zawarta na piśmie i określać w szczególności, w przypadku umowy o kredyt denominowany lub indeksowany do waluty innej niż waluta polska, szczegółowe zasady określania sposobów i terminów ustalania kursu wymiany walut, na podstawie którego w szczególności wyliczana jest kwota kredytu, jego transz i rat kapitałowoodsetkowych oraz zasad przeliczania na walutę wypłaty albo spłaty kredytu" [Dz.U., nr 165, poz. 984, stan prawny na dzień 24.04.2017]. Dodatkowo, ust. 3 w/w artykułu stanowi, że „w przypadku umowy o kredyt denominowany lub indeksowany do waluty innej niż waluta polska, kredytobiorca może dokonywać spłaty rat kapitałowo-odsetkowych oraz dokonać przedterminowej spłaty pełnej lub częściowej kwoty kredytu bezpośrednio w tej walucie" [Dz.U., nr 165, poz. 984 , stan prawny na dzień 24.04 .2017$]$. Zapisy te jednak w dalszym ciągu nie stoją na przeszkodzie określenia przez bank w umowie kredytu własnego sposobu ustalania kursu walutowego, jak to miało miejsce do momentu zmiany ustawy. Konieczność takiej regulacji w przyszłości wydaje się być jednak nieodzowna dla zapewnienia pełniejszej ochrony konsumenta na rynku usług bankowych.

Dodatkowym argumentem przemawiającym za przyjęciem odpowiedzialności banku za sytuację na rynku kredytów hipotecznych udzielanych we frankach jest niedostosowywanie się do rekomendacji $\mathrm{S}$, dotyczącej dobrych praktyk w zakresie zarządzania ekspozycjami kredytowymi zabezpieczonymi hipotecznie, stworzonej przez Komisję Nadzoru Bankowego (będącą swoistą „poprzedniczką" KNF) w 2006 roku i nowelizowaną przez KNF w latach kolejnych oraz rekomendacji T, która została przygotowana przez Komisję Nadzoru Finansowego w roku 2010 i nowelizowana trzy lata później. Dokumenty te zalecały bankom udzielającym kredytów w walucie obcej m.in. udzielanie kredytów hipotecznych w walucie obcej tylko kredytobiorcom odnoszącym przychód w tej walucie, rzetelną i kompleksową analizę zdolności kredytowej z założeniem stopy procentowej dla kredytów obcych co najmniej równą dla kredytów złotówkowych, czy chociażby zalecenie szczegółowego i przejrzystego informowania kredytobiorcy o wpływie ryzyka na wysokość kwot rat i zmianę spreadów. 
W wyroku II CSK 750/15 Sąd Najwyższy, oddalając skargę kasacyjną mBanku uzasadnił, że brak należytego indywidualnego uzgodnienia warunków umowy naruszających interes klienta w zakresie ustalania kursu walutowego na podstawie tabel bankowych i powoduje niezwiązanie stron umowy w tym zakresie ex lege ze skutkiem ex tunc. Rozwiązanie to wydaje się słuszne. Banki, wykorzystując nieświadomość finansową konsumentów, nie uzgadniały indywidualnie postanowień rażąco naruszających interesy konsumentów, a za takie zdecydowanie należy uznać brak wpływu konsumenta na wartość wyboru kursu, po którym jego zadłużenie jest przeliczane i swobodne określanie tabel kursowych przez banki, w których spread sięgał nawet do 40 groszy przy kilku groszach spreadu w innych obszarach rynku.

Dodatkowo istotnym dla ,frankowiczów” wyrokiem jest orzeczenie Trybunału Sprawiedliwości Unii Europejskiej z dnia 21 grudnia 2016 r. w połączonych sprawach C-154/15, C-307/15 i C-308/15. Zgodnie z orzeczeniem: „Artykuł 6 ust. 1 dyrektywy Rady 93/13/EWG z dnia 5 kwietnia 1993 r. w sprawie nieuczciwych warunków w umowach konsumenckich należy interpretować w ten sposób, że sprzeciwia się on orzecznictwu krajowemu ograniczającemu w czasie skutki restytucyjne związane ze stwierdzeniem nieuczciwego charakteru - w rozumieniu art. 3 ust. 1 tej dyrektywy - warunku znajdującego się w umowie zawartej z konsumentem przez przedsiębiorcę jedynie do kwot nienależnie zapłaconych na podstawie takiego warunku po ogłoszeniu orzeczenia, w którym sąd stwierdził ów nieuczciwy charakter", co pozwala uznać, że bezskuteczność klauzul niedozwolonych powodujących rozliczenie kredytu w złotym, zamiast we frankach, bierze się pod uwagę nie od momentu uprawomocnienia orzeczenia, a zawarcia umowy.

\section{POSTULATY I DZIAŁANIA LEGISLACYJNE NA RZECZ KREDYTOBIORCÓW KREDYTÓW WALUTOWYCH}

W licznych orzeczeniach sądowych, prezentowanych chociażby przez portal www.pomocfrankowiczom.pl, coraz częściej rozstrzyga się spory na korzyść kredytobiorcy. Sentencje w głównej mierze opierają się na uznaniu bankowych praktyk za niedozwolone wykorzystywanie klauzul abuzywnych. Dzięki takim rozstrzygnięciom strony uzyskują ,,przekształcone” na złotego umowy kredytowe wynikłe z bezskuteczności zawartych postanowień dotyczących sposobów wyliczania zobowiązania w odniesieniu do kursu franka. Zwraca się jednak coraz częściej uwagę na potrzebę pomocy osobom najbardziej poszkodowanym, biorącym kredyty we frankach szwajcarskich tylko dlatego, że nie posiadały zdolności kredytowej dla świadczenia w walucie polskiej, posiadającym niskie dochody i majątki, które nie mogą sobie poradzić z obsługą kredytu.

Jednym z pomysłów na pomoc „,frankowiczom” jest ustawa z dnia 9 października 2015 roku o wsparciu kredytobiorców znajdujących się w trudnej sytu- 
acji finansowej, którzy zaciągnęli kredyt mieszkaniowy. Jej istotnym założeniem jest realizowana za pośrednictwem Banku Gospodarstwa Krajowego pomoc w formie zwrotnego wsparcia finansowego osobom fizycznym, które znajdują się w trudnej sytuacji finansowej i posiadają kredyt mieszkaniowy, wyrażony w jakiejkolwiek walucie obcej. Warunkiem takiej pomocy jest bezrobocie kredytobiorcy, ponoszenie przez niego miesięcznych kosztów obsługi kredytu mieszkaniowego w wysokości wyższej niż $60 \%$ dochodów osiąganych przez gospodarstwo domowe lub miesięcznego dochodu gospodarstwa domowego jednoosobowego mniejszego niż 461 zł, a wieloosobowego - 316 zł pomnożonej przez liczbę członków gospodarstwa. Świadczenie takiej pomocy nie może przekroczyć 1500 zł miesięcznie, jest udzielane maksymalnie na okres 18 miesięcy i wypłacane w ratach miesięcznych. To udzielanie pomocy, odpowiadające na potrzeby poszkodowanych kredytobiorców, których sytuacja pogorszyła się przez nieodpowiedzialne działanie banków, jest postulatem słusznym. Uwzględnia pomoc dla osób zaciągających kredyty nie tylko w walucie obcej, ale także w walucie krajowej. Dodatkowo, nie obciąża finansów państwowych w sposób nadmierny - jest traktowane jako świadczenie pokrywane $\mathrm{z}$ utworzonego na potrzeby ustawy Funduszu Wsparcia Kredytobiorców. Zgodnie z art. 16 ust. 1 w/w ustawy, „Środki Funduszu w dniu jego uruchomienia wynoszą 600000000 zł", z kolei ust. 2 tegoż artykułu wskazuje na źródło pokrywające Fundusz: „Na Fundusz w dniu jego uruchomienia składają się wpłaty kredytodawców proporcjonalnie do wielkości posiadanego portfela kredytów mieszkaniowych dla gospodarstw domowych, których opóźnienie w spłacie kapitału lub odsetek przekracza 90 dni”. Kredytodawca z kolei jest definiowany w ustawie jako „bank krajowy, oddział instytucji kredytowej, oddział banku zagranicznego, o których mowa w art. 4 ust. 1 pkt 1, 18 i 20 ustawy z dnia 29 sierpnia 1997 r. - Prawo bankowe albo spółdzielczą kasę oszczędnościowokredytową, które udzieliły kredytu mieszkaniowego" [Dz.U. 2015, poz. 1925, stan prawny na dzień 24.04.2017]. Uwzględniając przykładowo definicję oddziału banku zagranicznego (,oddział banku zagranicznego - jednostkę organizacyjną banku zagranicznego wykonującą w jego imieniu i na jego rzecz wszystkie lub niektóre czynności wynikające $\mathrm{z}$ zezwolenia udzielonego temu bankowi, przy czym wszystkie jednostki organizacyjne danego banku zagranicznego odpowiadające powyższym cechom, utworzone na terytorium Rzeczypospolitej Polskiej, uważa się za jeden oddział") [Dz.U. 2015, poz. 1925, stan prawny na dzień 24.04.2017] okazuje się, że źródła finansowania pochodzące od banków, przekazywane są na potrzeby kredytowe osób, które stały się bezrobotne w skutek zdarzeń losowych. Oznacza to faktycznie, że kredytodawcy, będąc przecież przedsiębiorstwami nastawionymi na zysk, ponoszą odpowiedzialność za skutki zdarzeń, do których swoim działaniem nie doprowadziły. Taką regulację należy ocenić zdecydowanie w sposób negatywny, ponieważ banki, które - oczywiście - powinny ponieść odpowiedzialność za skutki wynikające ze swojego postępowania, jak 
na przykład stosowanie nieuczciwych praktyk, nie powinny być obarczane wykonywaniem socjalnej funkcji państwa.

Wiosną 2017 roku prowadzone są prace w podkomisjach sejmowych dotyczące prezydenckiego projektu ustawy o zasadach zwrotu niektórych należności wynikających z umów kredytu i pożyczki, zwanego „ustawą frankową”. Zakłada on zwrot spreadów naliczonego powyżej 0,5\% kursu sprzedaży/kupna NBP, pobranych przez banki w okresie od 1 lipca 2000 roku do 26 sierpnia 2011 roku (od tego momentu zaczęła funkcjonować tzw. ustawa antyspreadowa). Limit zwrotu ma być ustalony w wysokości 350 tysięcy złotych na jednego kredytobiorcę, a w przypadku limitu kapitału przewyższającego tę kwotę - ma być liczony tylko do kwoty 350 tys. zł.

W uzasadnieniu projektu Prezydenta Rzeczypospolitej Polskiej można przeczytać, że: „Celem projektowanej ustawy jest eliminacja skutków pobierania od konsumentów nienależnego świadczenia w postaci nadmiernie wysokich spreadów walutowych. Umowy kredytów hipotecznych indeksowanych oraz denominowanych do walut obcych zazwyczaj były zawierane na realizację przez konsumentów podstawowych celów bytowych, takich jak: zakup mieszkania, domu lub działki pod budowę domu. Kredyty te opiewały zatem na wysokie sumy i, co za tym idzie, szkody, jakie powstały po stronie konsumentów w związku ze stosowaniem spreadów bankowych, są znaczne. Opisany cel można osiągnąć wyłącznie poprzez ustawowe zobowiązanie do dokonania zwrotu niektórych świadczeń wynikających z umów kredytu i pożyczki, jako świadczeń pobranych nienależnie, na mocy klauzul preferujących jedną ze stron i wyposażających ją w prawo samodzielnego ustalania wysokości zobowiązania drugiej" [Projekt ustawy o zasadach zwrotu..., druk nr 811: 22-23]. Z takim stwierdzeniem nie sposób się zgodzić. Ewentualna ingerencja ustawodawcy w stosunki cywilnoprawne nie jest warunkiem koniecznym do uzyskania efektu ,eliminacji skutków pobierania od konsumentów nienależnego świadczenia", zwłaszcza że negatywne skutki takich zachowań banków zaczęły być eliminowane przez orzecznictwo przed wejściem projektowanej ustawy w życie, jak chociażby orzeczenie w zakresie niezwiązania konsumenta rażąco naruszającymi jego interes niedozwolonymi postanowieniami umownymi, orzeczone przez Sąd Najwyższy we wspomnianej wyżej sprawie (II CSK 750/15). Potwierdzenie tego stanowiska daje sam projektodawca. W artykule 13 projektu ustawy stanowi, że „Skorzystanie przez konsumenta z uprawnień przewidzianych niniejszą ustawą nie ogranicza uprawnienia konsumenta do wszczęcia lub kontynuowania postępowań sądowych w zakresie roszczeń związanych z umową kredytu". Trudno zaś nie uznać, że uzyskanie odszkodowania w postępowaniu cywilnym nie likwiduje negatywnych skutków pobierania nienależytego świadczenia.

Negatywnie ocenić należy także pomysł ewentualnej ingerencji ustawodawcy w sferę sporów cywilnoprawnych, które zaczęły być rozpatrywane na drodze 
sądowej, często zwycięskiej dla kredytobiorców kredytów we frankach szwajcarskich. Dobrze uzasadnionym zdaje się być stanowisko prof. Leszka Balcerowicza, który uważa, że przeciętny „frankowicz” jest lepiej sytuowany od przeciętnego „złotówkowicza” i nie ma moralnej podstawy do traktowania lepiej osób zadłużonych we frankach, ponieważ wiedzieli oni wcześniej o ryzyku walutowym i płacili mniejsze raty kredytowe. Chcieli zarobić na swego rodzaju spekulacji walutowej. Istniejące roszczenia, często zasadne, powinny być rozwiązywane na drodze sądowej, ponieważ zasada równego traktowania obywateli, zdaniem prof. Balcerowicza, nie pozwala na ,płacenie przez państwo za błędy frankowiczów pieniędzmi obywateli" [www1: film wideo].

Istotnym aspektem, poruszanym przez prof. Witolda Orłowskiego, jest ewentualna realizacja postulatu obciążenia banków kosztami pomocy kredytobiorcom - takie działania wiązałyby się w rzeczywistości z przerzuceniem kosztów pomocy na klientów [www3]. Jest to zatem, przy założeniu pociągnięcia do odpowiedzialności banków na drodze cywilnoprawnej, potwierdzenie tezy o niedopuszczalności przenoszenia realizacji funkcji redystrybucyjnej państwa na banki komercyjne.

\section{PODSUMOWANIE}

Niewątpliwie, zagadnienie kredytów denominowanych i kredytów indeksowanych we frankach szwajcarskich nie tylko budzi wiele emocji, ale jest wrażliwym punktem polskiego systemu finansowego. Nierzetelna ocena zdolności kredytowej przez banki, udzielanie kredytów konsumentom, którzy nie spełniali wymogów na otrzymanie kredytów w złotym polskim, zbyt optymistyczne przewidywania konsumentów co do stabilności kursów walutowych, a także stosowanie przez banki niedozwolonych praktyk rynkowych spowodowało problemy w terminowym regulowaniu należności przez konsumentów. Odpowiedzialność banków za ten stan rzeczy powinna być jednak dochodzona na drodze postępowania cywilnego przez wystąpienie z roszczeniami cywilnoprawnymi.

Pomocną dłoń do "frankowiczów” wyciągnął ustawodawca, który w ustawie z dnia 9 października 2015 roku o wsparciu kredytobiorców znajdujących się $\mathrm{w}$ trudnej sytuacji finansowej, którzy zaciągnęli kredyt mieszkaniowy przewidział zwrotną pomoc w formie pożyczki. Rozwiązanie to mogłoby być dobre pod warunkiem nierealizowania funkcji redystrybucyjnej, czy też socjalnej państwa przez obciążanie banków udzielających kredytów mieszkaniowych za zdarzenia, za które odpowiedzialności nie ponoszą.

Przedstawienie Parlamentowi RP projektu ,ustawy frankowej” przez Prezydenta Rzeczypospolitej Polskiej wydaje się za nieuzasadnione w perspektywie coraz częstszego występowania „frankowiczów” na drogę sądową oraz uzyskiwania żądanych rozstrzygnięć. Orzecznictwo zauważyło problem stosowania 
przez banki nieuczciwych praktyk rynkowych, chociażby swobodnego ustalania kursów przez kredytodawców według tabeli bankowych i coraz częściej orzekało stosowanie niewłaściwych praktyk wobec konsumentów.

Działania legislacyjne ustawodawcy powinny być przesunięte $\mathrm{w}$ kierunku zapobiegania ryzykom kredytów walutowych. W dalszym ciągu pozostaje nierozstrzygnięta kwestia swobodnego ustalania wysokości spreadów, która mogłaby przykładowo być odnoszona do kursów walutowych podawanych przez NBP. Ustawodawca powinien też nakreślić szersze obowiązki informacyjne dotyczące rodzajów ryzyka związanych z kredytem walutowym oraz działania mające na celu ograniczenie stosowania niewłaściwych praktyk bankowych.

Wszystkie zaś działania ustawodawcy, powinny być przede wszystkim podejmowane roztropnie, uwzględniając wrażliwość systemu finansowego i zapewniając mu należyte bezpieczeństwo.

\section{BIBLIOGRAFIA}

Jurkowska-Zeidler A., 2016, Asymetria ryzyka a zasada sprawiedliwości spotecznej na tle problemu kredytów we frankach szwajcarskich, Gdańskie Studia Prawnicze, Tom XXXV, Gdańsk.

Miklaszewska E. (red.), 2010, Bank na rynku finansowym. Problemy skali, efektywności i nadzoru, Wolters Kluwer Polska, Warszawa.

Orzeczenie Trybunału Sprawiedliwości Unii Europejskiej z dnia 21 grudnia 2016 r. w połączonych sprawach C-154/15, C-307/15 i C-308/15.

Orzeczenie Sądu Najwyższego z dnia 8 września 2016 r. w sprawie II CSK 750/15.

Orzeczenie Trybunału Sprawiedliwości Unii Europejskiej z dnia 3 grudnia 2015 r. w sprawie C-312/14.

Projekt ustawy o zasadach zwrotu niektórych należności wynikających z umów kredytu i pożyczki (druk nr 811).

Ustawa z dnia 9 października 2015 r. o wsparciu kredytobiorców znajdujących się w trudnej sytuacji finansowej, którzy zaciągnęli kredyt mieszkaniowy, Dz.U. 2015, poz. 1925.

Ustawa z dnia 29.07.2011 r. o zmianie ustawy - Prawo bankowe oraz niektórych innych ustaw, Dz.U., nr 165, poz. 984.

Ustawa z dnia 29 sierpnia 1997 r. Prawo bankowe, Dz.U. 1997, nr 140, poz. 939.

[www1] http://biznes.onet.pl/wiadomosci/kraj/trzy-projekty-tzw-ustawy-frankowej-w-sejmie-dzispierwsze-czytanie/y8c8x5.

[www2] http://forsal.pl/artykuly/1021734,austria-kredyty-we-frankach-chf-austria-najbardziej-ufran kowionym-krajem-w-europie.html.

[www3] http://natemat.pl/74331,zadluzeni-we-frankach-jak-powodzianie-czy-panstwo-powinnopomagac-frankowiczom-oto-argumenty-obu-stron.

[www4] https://www.knf.gov.pl/Images/Skutki_finansowe_projektu_tcm75-46244.pdf.

[www5] https://www.knf.gov.pl/opracowania/sektor_bankowy/raporty_i_opracowania/publikacje_ sektora_bankowego/. 


\title{
WHEN COMES LACK OF „SWISS PRECISION” - FEW WORDS IN LEGAL AND ECONOMIC ASPECT ABOUT LOANS IN SWISS FRANC TAKEN BY POLISH DEBTORS
}

\begin{abstract}
Article shows the main problems of loans incurred in Suiss francs by polish debtors in period of time 2007-2015. Author sets out with the aim of analysing polish financial market and tries to answer a questions about banks' responsibility for increased debtors' commitments, presents judgments of courts of law and evaluates legislative actions, which are expected to help polish debtors. Author points at necessity of foreign currency loans risk reduction.
\end{abstract}

Keywords: foreign currency loan, responsibility of the banks, unfair market practices, Swiss franc, legislative action. 